\title{
A visegrádi országok perspektívája az Európai Kutatási és Innovációs Térségben
}

A tanulmány az úgynevezett „visegrádi országok” (V-4: Csehország, Lengyelország, Magyarország és Szlovákia) felzárkózási és integrációs esélyeit vizsgálja az Európai Unió egyik fő stratégiai célkitűzésével, az Európai Kutatási Térség (European Research Area, ERA) megteremtésével kapcsolatban. A szerző megállapítja, hogy a visegrádiak globális gazdasági és különösen kutatás-fejlesztési potenciálja szerény, annak ellenére, hogy világpolitikai értelemben a glóbusz fejlettebb országaihoz tartoznak. Hangsúlyozza, hogy a V-4 régióban a vállalkozások üzleti környezetének rendbetétele nélkül nem várható az innovációk és a K+F iránti kereslet érdemi élénkülése. A tanulmány fontos állítása a „visegrádi paradoxon”: bár nemzetközi összehasonlításban a kutatók létszáma az elköltött GERD-hez, a BERD-hez és a GDP-hez képest is jelentős, a visegrádiak innovációs teljesítménye mégsincs összhangban a tudományos teljesítményükkel (a szakadék nagyobb, mint az EU-15 országok esetében). Az ERA-ba való integrálódást gátolja a V-4 országok regionális fejletlensége (a kiválósági központok alacsony száma) a K + F területén. Az ERA megteremtését szolgáló és nagy külső gazdaságpolitikai nyomásként jelentkező uniós mechanizmusok jelentős ösztönző erőként hatnak a V-4 országok döntéshozóira és véleményformálóira, ám a nemzeti innovációs rendszerek piacgazdasági transzformációja a V-4 régióban ezzel együtt is lassú folyamatnak ígérkezik.

Kulcsszavak: visegrádi országok, versenyképesség, ERA, innováció, $K+F$

\section{Szerzői információ:}

\section{Borsi Balázs}

Közgazdász, a GKI Gazdaságkutató ZRt. vezetố kutatója. Szakterülete az innováció és a tudásgazdaság. Az Európai Unió keretprogramjaiban több kutatásban (pl. a csatlakozó országok kiválósági központjainak a benchmarkjait feltáró RECORD-projektben) vállalt fontos szerepet. Jelenleg az EU két nagy innovációkutatási programjában múködik közre vezetóként.

E-mail: borsib@gki.hu

Így hivatkozzon erre a cikkre:

Borsi Balázs. „A visegrádi országok perspektívája az Európai Kutatási és Innovációs

Térségben”. Információs Társadalom VI, 3. szám (2006): 54-70.

$=$ https://dx.doi.org/10.22503/inftars.VI.2006.3.4

A folyóiratban közölt müvek

a Creative Commons Nevezd meg! - Ne add el! - Így add tovább! 4.0

Nemzetközi Licenc feltételeinek megfelelően használhatók. 
Borsi Balázs*

\section{A visegrádi országok perspektívája az Európai Kutatási és Innovációs Térségben}

\section{Kiindulópontok}

Ma már számos tudományos kutatás által igazolt és közhelyszámba menô megállapítás, hogy a 21. században a gazdasági fejlődés motorja a kutatás-fejlesztés és az innováció. ${ }^{1}$ A modern piacgazdaságok a globális piacokba integráltan múködnek, és versenyképességük megốrzése érdekében nemzeti innovációs rendszereik legfóbb intézményi szereplôi (a vállalatok, a kutató-fejlesztő intézmények, az egyetemek, a hídképzók, a finanszírozók) kisebb-nagyobb regionálisan koncentrált közösségeket (hálózatokat, klasztereket) alkotva igyekeznek megfelelni korunk kihívásainak.

A visegrádiaknak nevezett, földrajzilag összefüggó területet alkotó országcsoport 1991-ben, Csehszlovákia, Lengyelország és Magyarország köztársasági elnökei, Václav Havel, Lech Walesa és Göncz Árpád közös deklarációjával jött létre. A visegrádi országok együttmúködésének legnagyobb eredményeként 1992-ben Krakkóban megkötötték a Közép-Európai Szabadkereskedelmi Megállapodást (Central European Free Trade Agreement, CEFTA). Csehszlovákia felbomlását követően, 1993-tól V-4-ekról beszélhetünk. A V-4 országok a CEFTA-ban az Európai Unió 2004. évi bóvítéséig vettek részt. ${ }^{2}$ Az uniós taggá válást követően a V-4 országcsoport látványos politikai deklarációkat tesz ugyan, ám általános vélemény, hogy mára a visegrádi együttmúködés kiüresedett.

A visegrádi együttmúködés legutóbbi fejleményeivel éppen ellentétes irányt látszik venni az ERA, az Európai Kutatási Térség ${ }^{3}$ dinamikája. A térség kialakítására irányuló törekvés egyidős a lisszaboni stratégiával ( $E C, 2000 \mathrm{~b})$, és a politika szintjén gyakran mint az Európai Kutatási és Innovációs Térség programja jelenik meg. ${ }^{4}$ A kibővülő ERA fő katalizátora a 2007-2013 között bő 70 milliárd euróból megvalósuló 7. keretprogram lesz.

2005-2006-ban Magyarország látja el a V-4 országok elnöki teendóit, és a visegrádiak identitásának erôsítése és az Unióban való közös fellépés mellett az infrastruktúra és a kutatás-fejlesztés területén irányoz elő együttmúködést. Ahhoz, hogy ez ne pusztába kiáltott szó maradjon, meg kell értenünk, hogy ez a nagyjából azonos társadalmi-kulturális gyökerekkel bíró régió reálisan mit adhat hozzá Európa $\mathrm{K}+\mathrm{F}$-jéhez, illetve inno-

* Kutatásvezetố, GKI Gazdaságkutató ZRt.

${ }^{1} \mathrm{~A} \mathrm{~K}+\mathrm{F}$ és az innováció fogalmát és módszertani ismérveit az $O E C D$ (2002) és $O E C D$ (2005) alapján értelmezem.

${ }^{2}$ A szabadkereskedelmi megállapodást ma már az EU elốszobájának tekintik. A mai CEFTA-tagok: Bulgária, Horvátország, Macedónia és Románia.

${ }^{3}$ Angolul: European Research Area.

${ }^{4}$ A 2004 második félévében elnöklô Hollandia már így nevezte az ERA-t, ma azonban még az ERA elnevezés az elterjedtebb. 
vációihoz, napjaink talán legfontosabb globális versenyt alakító folyamataihoz. Milyen versenyképességi potenciált, mekkora $\mathrm{K}+\mathrm{F}$ erôt képviselnek a V-4 országok? Milyen versenyképességi és innovációs háttérrel igyekeznek boldogulni a nemzetközi versenyben? Mely területeken segítheti jól a V-4-ek gazdaságpolitikája az integrációt? Melyek a fó innovációs és $\mathrm{K}+\mathrm{F}$ politikai irányok, és hogyan viszonyulhat a visegrádi térség az ERA-hoz? A tanulmányban elsősorban ezekre a fő kérdésekre keresem a választ.

\section{A visegrádiak globális versenypozíciója}

Ma az Egyesült Államok, az Európai Unió és Ázsia, azon belül is elsősorban Japán a világ gazdasági erốközpontjai. A visegrádi országok népessége az Egyesült Államokénak az egyötöd részét teszi ki, ám a V-4-ek összesített $G D P$-je csupán egy huszadrésze az USA-énak, s ezek az arányok nagyon hasonlóak az EU-15-ökkel, illetve a Japánnal való összevetésben is. Bár a visegrádi országcsoport politikai értelemben ma már egyértelmúen a glóbusz fejlettebb térfeléhez tartozik, gazdasági súlya és jelentősége lényegesen kisebb, mint ami a lakosság lélekszámából következne. Ilyen helyzetben csak nagyon kevés ország van a világban, esetleg Argentína említhetố hasonló példaként.
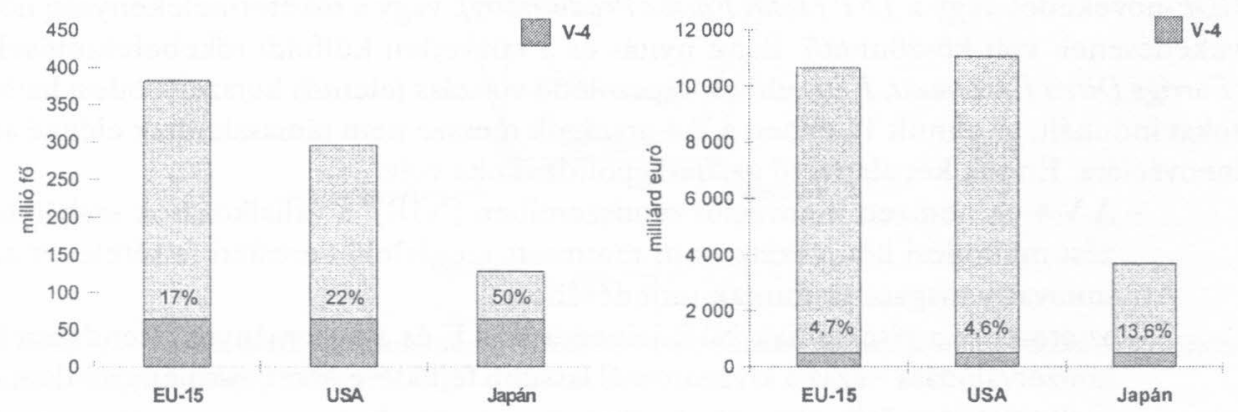

1. ábra. A V-4 országok részaránya a népességhez (2003) és a GDP-hez (2006) képest Forrás: számítások az Unctad és az Eurostat adatai alapján

A szerény gazdasági összteljesítményt jól jellemzi a V-4 országok termelékenységi színvonala, például az egy foglalkoztatottra jutó hozzáadott érték is: vásárlóerő-paritáson számolva az Egyesült Államok termelékenységének körülbelül a felét, az EU-15 országokénak körülbelül a $60 \%$-át, míg a japán termelékenységi szintnek körülbelül a kétharmadát éri el. Vásárlóerố-paritáson számolva a V-4 országok termelékenységi elmaradása - Magyarország kivételével - a szolgáltatásokban kisebb, mint az iparban.

\footnotetext{
${ }^{5}$ Igaz az is, hogy a szolgáltatások $G D P$-jének számítási hibája jóval magasabb, mint az ipari tevékenységeké.
} 


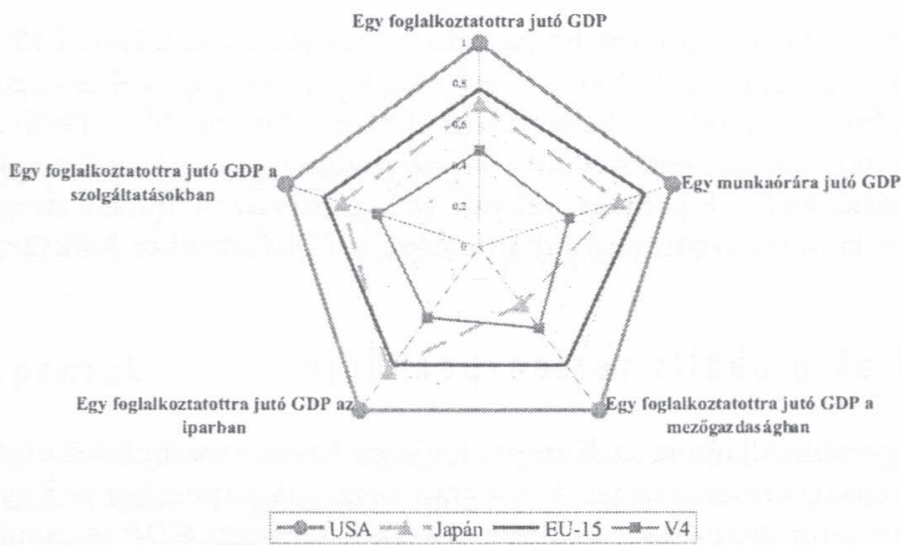

2. ábra. A visegrádi országok néhány termelékenységi mutatója* nemzetközi összevetésben:

$\mathrm{USA}=1(2005-2006)$

* Vásárlóerố-paritáson számolva

Forrás: számítások az IMD World Competitiveness Yearbook 2006 adataiból

Általában elmondható, hogy a V-4 országokban az átalakulás utáni sokkot követố $G D P$-növekedés vagy a TFP (Total Factor Productivity), vagy a tóketermelékenység növekedésének volt köszönhetố. Bár a nyitás és a közvetlen külföldi tốkebefektetések (Foreign Direct Investment, FDI) ehhez kapcsolódó vonzása jelentős korszerúsödési hatásokat indukált, az elmúlt 15 évben a V-4 országok messze nem támaszkodtak eléggé az innovációra. Ennek két alapvetô gazdaságpolitikai oka volt:

- A V-4-ek nemzeti innovációs rendszereiben $(\mathrm{NIR})^{6}$ a vállalkozások szabályozási-múködési környezete nem teremtett megfeleló keresleti feltételeket az innovatív magatartásformák terjedéséhez;

- az átmenet a visegrádiak NIR-jeiben a $\mathrm{K}+\mathrm{F}$ és a tudományos alrendszerek konzerválódása - azaz a kívánatosnál lassúbb fejlődése és teljesítményjavulása mellett ment végbe.

A továbbiakban részletesen is alátámasztom a fenti két állítást.

\section{Szabályozási környezet és innováció}

Az intézményi közgazdaságtannak nevezett közgazdaságtani irányzat a 20. század elsố felében, Coase (1937) úttörố munkájával bontott zászlót. Az irányzat alapkérdései közé tartozik pl. az ún. tranzakciós költségeknek a vizsgálata (vagyis - leegyszerúsítve annak tanulmányozása, hogy a piacokon az egyes intézményi megoldások közül melyik jár alacsonyabb költséggel). A vállalkozások múködési környezete erôteljesen hat a

${ }^{6}$ A nemzeti innovációs rendszerek kialakításának és múködésének ma már önálló szakirodalma van. Egy ismert meghatározás szerint a NIR „azon elemek és kapcsolatok halmaza, melyek az új és gazdaságilag hasznos tudás termelésében, terjesztésében és hasznosításában játszanak közre [...], és amelyek vagy az országhatáron belül találhatók, vagy gyökerük oda vezet vissza." - Bengt-Åke Lundvall (OECD, 1997, 10.) 
tranzakciós költségekre és a vállalatok versenyképességére. Ezért a nemzeti innovációs rendszer egészének - benne a tudománynak és a kutatás-fejlesztésnek - a teljesítményét is nagyban meghatározza a vállalkozások szabályozási-múködési környezete.

Nem meglepó ezért, hogy a nemzetgazdaságok versenyképességének komplex mérésére szolgáló nemzetközi rangsorok kialakításakor mind tudományos-technológiai, mind az üzleti környezetre vonatkozó tényezóket egyaránt figyelembe vesznek. ${ }^{7}$

A Versenyképességi világévkönyv (World Competitiveness Yearbook) 2006. évi kötetében az intézményi múködésre vonatkozóan szereplő adatok szerint a V-4 országokban egyedül a munkaerố-piaci szabályozás kedvezóbb, mint az EU-15-öknél. ${ }^{8}$ Az évkönyv adatai különösen a korrupció, a bürokrácia és az átlátható kormányzati múködés tekintetében tüntetik fel kedvezốtlen színben a visegrádiakat. Természetesen joggal tehető fel a kérdés, hogy ezek a mérőszámok hogyan függenek össze az innovációs tevékenységgel? Az alábbi ábrán a Versenyképességi Évkönyo számait az Egyesült Államok pozíciójához képest ábrázoltam (minél rosszabb egy-egy mutató, annál közelebb található az ötszög középpontjához):

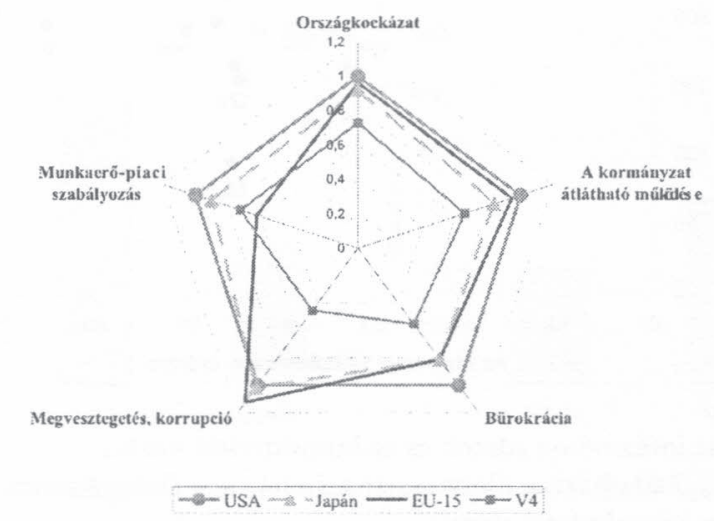

3. ábra. A visegrádi országok intézményi múködésének néhány mutatója nemzetközi összevetésben: USA $=1 *(2005-2006)$

* A mutatók magas értéke kedvezô, alacsony értéke kedvezốtlen helyzetet jelez.

Forrás: számítások az IMD World Competitiveness Yearbook 2006 adataiból.

${ }^{7}$ Két ismert példát idézek. A Világgazdasági Fórum (World Economic Forum) globális versenyképességi jelentése (The Global Competitiveness Report) vállalatvezetôi véleményekre alapozva vizsgálja a versenyképesség tényezőit. Ezeket két index, a növekedési versenyképességi index (Growth Competitiveness Index, GCI, @ Jeffrey Sachs) és a vállalati versenyképességi index (Business Competitiveness Index, BCI, (C) Michael Porter) összegzi. A $G G I$ három alapja (i) a makrogazdasági környezet minősége, (ii) az ország állami intézményeinek állapota, és (iii) a mû́szaki-technológiai felkészültség. A svájci székhelyú Nemzetközi Menedzsmentfejlesztési Intézet (International Institute for Management Development, IMD) által kiadott Versenyképességi világééö̈nyv (World Competitiveness Yearbook) szakértôi véleményekre alapozva készül, az alábbi négy fö témában, melyeken belül öt-öt résztémát elemeznek: (i) A gazdasági teljesítményt a hazai gazdaság, a külkereskedelem, a külföldi befektetések, a foglalkoztatottság és az áralakulás szerint vizsgálják. (ii) A kormányzati hatékonyság elemzési-szempontjai: állami finanszírozás, fiskális politika, intézményrendszer, vállalati jog és társadalmi keretek. (iii) A vállalati hatékonyságot a termelékenység, a munkaerôpiac, a vállalatvezetési gyakorlat, az attitúdök és az értékek szerint osztályozzák. (iv) Végül az infrastruktúrát az alap-infrastruktúra, a múszaki-technológiai infrastruktúra, a tudásbázis, az egészségügyi-környezeti tényezók és az oktatás mérőszámaival minôsítik.

${ }^{8}$ Az európai munkanélküliségi trendek összhangban vannak ezzel a megállapítással. 
Ha a Világbank Doing Business adatbázisának jóval „,keményebb” intézményi mutatóit elemezzük, kimutatható, hogy igenis létezik kapcsolat az innovációk és a szabályozási gyakorlat között. Amennyiben egy adott országban hatékonyabb és rugalmasabb a szabályozás, akkor ott jó eséllyel több az innováció is. ${ }^{9}$ Összességében mindez közvetetten, ám nagyon erôteljesen hat az innovációs (és így a $\mathrm{K}+\mathrm{F}$, illetve tudományos) teljesítményre. A V-4 országok esetében az intézményi hatás meglehetôsen kedvezốtlen.

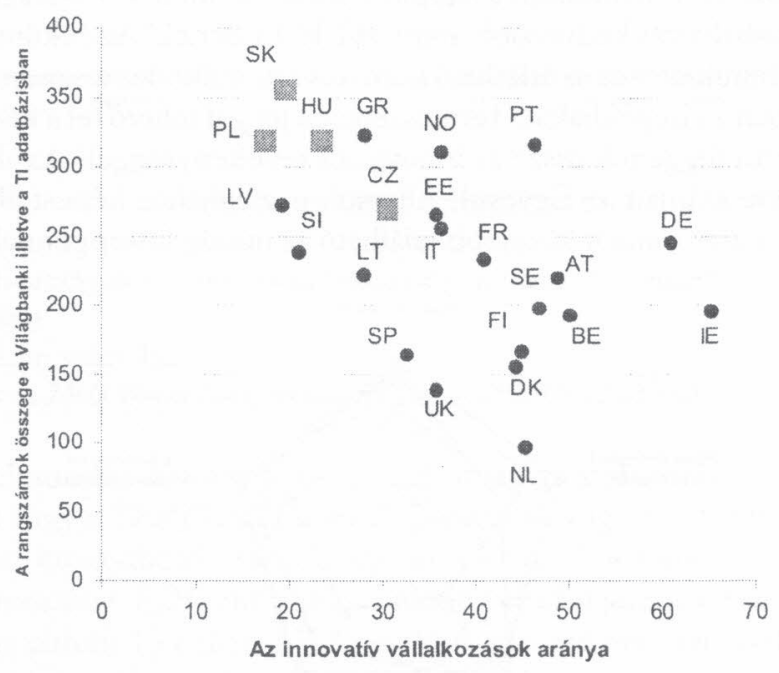

4. ábra. Összefüggés az intézményi adatok és az innovativitás között

Forrás: az Eurostat CIS-3 adatbázisa, illetve saját számítások a Doing Business 2005 és a Transparency International adatai alapján.

A vállalkozások üzleti-intézményi környezetének mutatói az Egyesült Államokban szinte minden tekintetben jobbak, mint az Európai Unióban, a V-4 országok esetében pedig a világbanki mérôszámok az Unión belül is csupán az alsó harmad környékére pozicionálják Csehországot, Lengyelországot, Magyarországot és Szlovákiát. A V-4 országokban tehát a szabályozási gyakorlat hátrányosan érinti az innovációkat megvalósító vállalkozói kört, és ez eleve szúkíti mind a vállalkozási, mind a kormányzati kutató-fejlesztố szektorral szemben támasztott üzleti elvárásokat és keresletet. Minderre tekintettel kell lenni, amikor az innovációs és $\mathrm{K}+\mathrm{F}$ aktivitás alacsony szintjét elemezzük.

${ }^{9}$ Az EU 23 tagállamára vizsgáltam az intézményi múködés világbanki mérôszámai és az innovációk közötti kapcsolatot (a Világbank adatbázisa a vállalkozások indításának, a munkaerốpiac rugalmasságának, az ingatlanszerzéssel kapcsolatos ügyintézésnek, a hitelfelvételi lehetőségeknek, a befektetốvédelemnek, a szerződések kikényszeríthetôségének és a vállalkozások megszüntetésének szabályozási gyakorlatára összpontosít). Országonként összeadtam a rangszámokat (azaz ha egy ország minden mérőszám tekintetében a legjobb, akkor a rangszámok összege 21, ha minden esetben az utolsó, akkor ez a mutató $21 \square 23=483$ ), és megvizsgáltam, hogy a rangszámösszegek korrelálnak-e az innovatív vállalkozások arányával. A kapcsolator jellemzó lineáris korreláció jelentôs és szignifikáns (az együttható értéke -0,5). Részletesebben lásd Borsi, 2005. 


\section{A V-4 és az ERA}

Az Európai Kutatási Térség, az ERA létrehozása eredetileg a $\mathrm{K}+\mathrm{F}$ szektor európai méretú integrációjának koncepciója volt. 2006-ban a V-4-ek csupán humán potenciált jelenthetnek Európának, ugyanis ezek az országok a nemzeti statisztikai adatok szerint nagyon lemaradtak a világ kutatás-fejlesztési centrumaihoz képest. ${ }^{10}$

A globális $\mathrm{K}+\mathrm{F}$ versenyben a visegrádi országok a $G D P$-jükhöz képest lényegesen szerényebb pozíciót foglalnak el. Bár a kibővített EU csaknem minden hetedik polgára „visegrádi”, s a megtermelt GDP-ból minden huszonötödik euró cseh, lengyel, magyar vagy szlovák eredetú, a kutatás-fejlesztési eurókból csak minden hatvanadikat költik el a V-4 országokban. A vállalkozási kutatás-fejlesztési ráfordítások esetében a kép még keserúbb: az európai vállalkozások csak minden nyolcvanötödik $\mathrm{K}+\mathrm{F}$-re szánt eurót költik el Csehországban, Lengyelországban, Magyarországon vagy Szlovákiában.
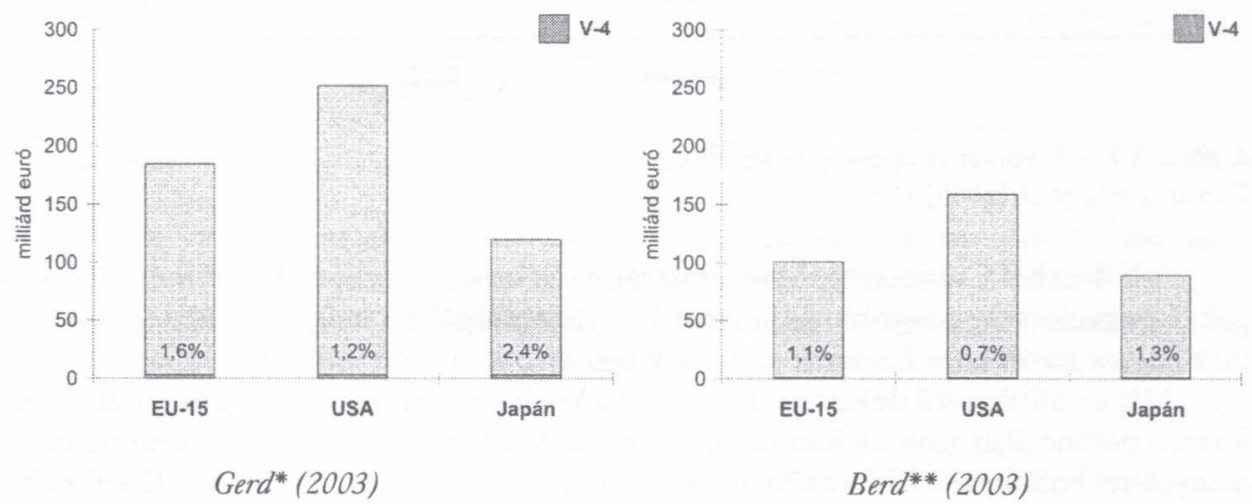

5. ábra

* Bruttó hazai $\mathrm{K}+\mathrm{F}$ ráfordítás (Gross Domestic Expenditure on $R$ \& $D$ )

** Vállalkozási $\mathrm{K}+\mathrm{F}$ ráfordítás (Business Expenditure on $R$ \& $D$ )

Forrás: számítások Eurostat adatok alapján

A visegrádiak helyzetét Török et al. [2005] részletesebb statisztikai és $\mathrm{K}+\mathrm{F}$ politikai elemzéséból is megállapíthatjuk. Török és szerzőtársai szerint a világ tudományos és kutatás-fejlesztési versenyterepe hat nagyobb országcsoportban rajzolható fel. A K + F trendeket diktáló szereplók között is meg kell különböztetni az abszolút méretük miatt is már versenyképes országokat és a nagyon hatékony, fejlett kicsiket. A versenyben néhány közepes méretú és teljesítményú, valamint néhány nagyobb méretú ország még megmutatja magát, a többiek szerepe marginális.

\footnotetext{
${ }^{10}$ Ez nem jelenti azt, hogy a V-4-ek néhány ritka és speciális kutatási területen ne lennének sikeresek, erre a késóbbiekben hozok fel néhány példát.
} 


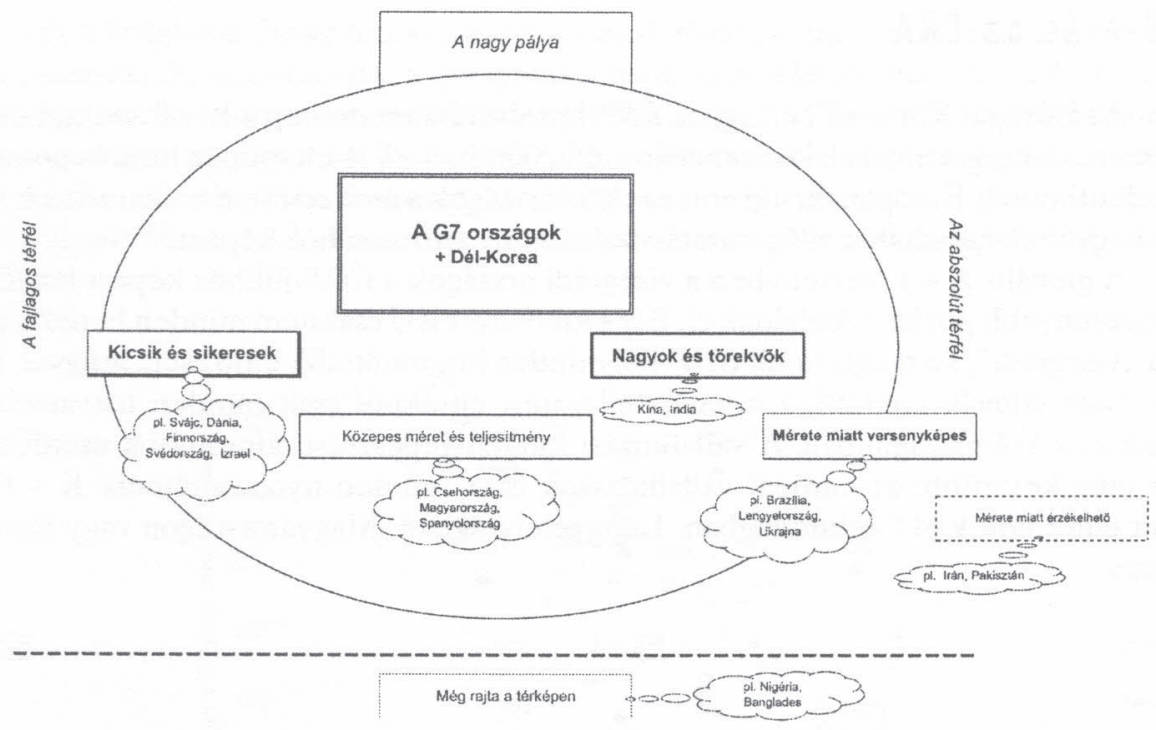

6. ábra. A K + F versenyképesség világtérképe

Forrás: Török et al. [2005] 198.

A V-4-ekból Csehország, Magyarország és Szlovákia közepes K + F méretú országok, Lengyelország nagyobb. Mindazonáltal összességében még ez a „közepesség” is csak nagyon szerény $K+F$ méretet jelent a világnak ebben a 65 millió foós régiójában.

Míg a politikai ízú deklarációk szintjén a V-4 lényeges tudományos és kutatási-fejlesztési potenciálját szokták kiemelni, ${ }^{11}$ a korosodó Európában - amely felismerte tudományos-technológiai leszakadásának aggasztó trendjeit, és amelyben a V-4 K + F ráfordításainak mérete szinte jelentéktelen - sok kutató eleve a tengerentúlon szerzi meg a doktori fokozatát, és késóbb is szívesen marad, vállalkozik az USA-ban. A jelenség része az ún. európai paradoxon ${ }^{12}$ problémakörének: hiába kiegyensúlyozott az EU „tudományos" teljesítménye (ami megmutatkozik például a végzett PhD-hallgatók magas számában vagy a publikációs teljesítményben), ha új termékek és technológiák bevezetésére, illetve a tudományos eredmények gyakorlati alkalmazására csak kevéssé képes. Európai szinten is fel kellett ismerni, hogy a tehetséges kutatók jelentős részét vonzza, ha létrehozott tudása a gyakorlatban is hasznosul (és emellett ez még jó üzletnek is bizonyul), ráadásul ez a múszaki fejlódésre és innovációkra alapozott versenyképességnek is az egyik fontos kulcsa. Az viszont az európai gazdaságpolitikai döntéshozók elốtt sem lehet titok, hogy a gazdaságban a humán tényezók megváltoztatása a leglassúbb folyamat, azaz lehet, hogy nagy a V-4-ek „,humán K + F potenciálja”, ám innovációs tartalékként történố mozgósításuk idôigénye is meglehetôsen nagy lehet!

${ }^{11}$ Lásd pl. az EC (2002) Key Figures címú kiadványát, amely a kibő́vülő humán kapacitásokat minôsíti „nagy potenciálnak".

${ }^{12} \mathrm{Az}$ elnevezést a European Commission (1995) jelentést tette széles körben ismertté. Magyarul részletes elemzést közöl Papanek (2003). 


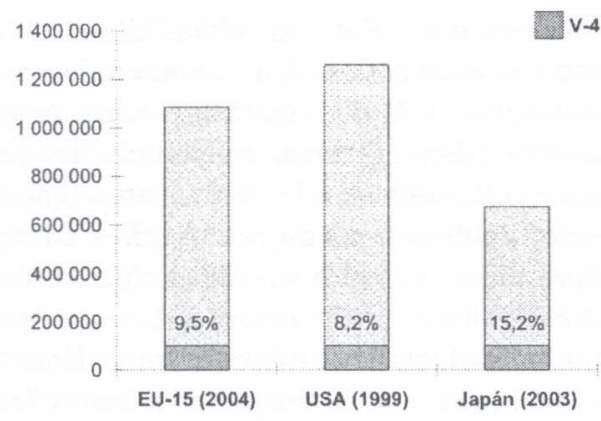

A kutatók létszáma

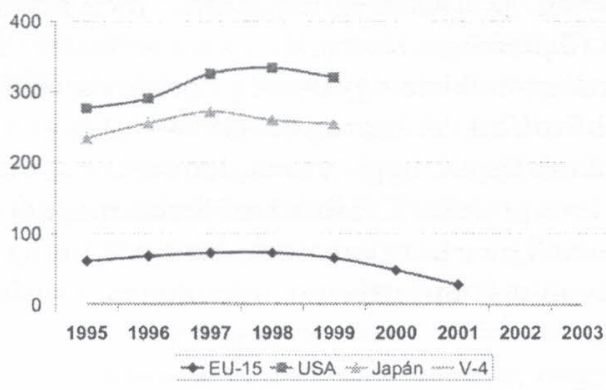

Egymillió lakosra jutó USPTO*-szabadalom

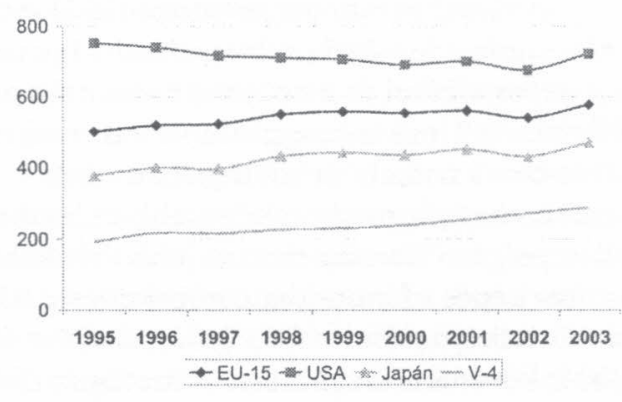

Egymillió lakosra jutó tudományos közlemény

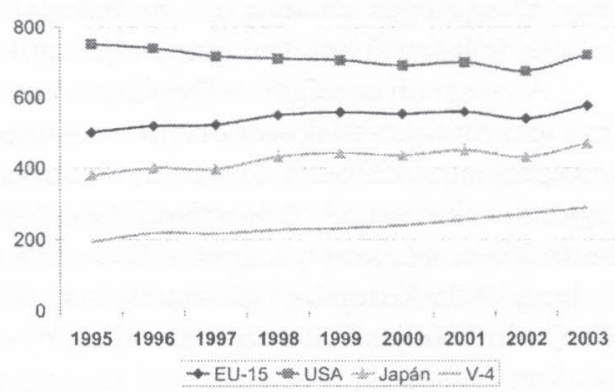

A csúcstechnológiai export részaránya az összes kivitelból (\%)

7. ábra

* United States Patent and Trademark Office.

Forrás: számítások az Eurostat, az UNCTAD és a National Science Foundation adatai alapján.

Így az európai paradoxon, ha a V-4 régióra koncentrálva vizsgáljuk, sajátosan torzul, és rögzíthető a „visegrádi paradoxon”: bár nemzetközi összehasonlításban a kutatók létszáma az elköltött $G E R D$-hez, a $B E R D$-hez és a $G D P$-hez képest is jelentôs, a V-4-ek innovációs teljesítménye még sincs összhangban a tudományos teljesítménnyel (a szakadék nagyobb, mint az EU-15-öknél - ezt az ábra a publikációk, illetve az USA-ban bejegyzett szabadalmak számán keresztül tükrözi).

Külön kiemelném a csúcstechnológiai export alakulását mint a V-4-ek innovációs rendszereinek egy csalóka mutatóját. A csúcstechnológiai export a fejlett gazdaságokban magas szellemi hozzáadott értéket testesít meg, és a V-4 országokban ezeknek a termékeknek a súlya az összkivitelben jóval alacsonyabb, mint az EU-ban. S bár a dinamika biztató, e mögött lényegében magyarországi (és részben csehországi) székhelyú, ám külföldi tulajdonú összeszerelő üzemek állnak, amelyek lényegében semmit nem profitálnak a helyi tudásból. ${ }^{13}$

${ }^{13}$ Azt, hogy a high-tech export mennyire elszakad a hazai $\mathrm{K}+\mathrm{F}$ folyamatoktól, a magyar eset jól jellemzi. Az üzleti szektor K + F-jének csaknem felét adó gyógyszeripar - amely nyilvánvalóan exportorientált 2000-ben az összes hazai high-tech exportból csupán 4,3\%-kal részesedett. Úgy vélem, ez közvetetten arra is utal, hogy a V-4 gazdaságokban - néhány kivételtốl eltekintve - a globális vállalati értékláncoknak egyelôre csak egy-egy rövid, K + F nélküli „szakasza” van jelen. 
Az Unió az európai paradoxon által megtestesített $\mathrm{K}+\mathrm{F}$ és innovációs kihívásokra más, európai léptékú problémákkal - így például az elöregedéssel, a munkaerôpiac rugalmatlanságával és a növekedésorientált gazdaságpolitikával - együtt igyekszik megfelelni. Az Unió legmagasabb szintú politikai döntéshozó fóruma, az Európai Tanács 2000-ben a lisszaboni stratégiában túzte ki azt a célt, hogy az EU tíz év alatt váljon a földkerekség legversenyképesebb és legdinamikusabb tudásalapú gazdaságává, amely állampolgárai számára több és jobb munkahelyet, illetve erôsebb szociális kohéziót biztosítva képes a fenntartható növekedésre (lásd $E C$ [2000]). Két év múlva az Unió pontosította elképzeléseit ( $E G, 2002$ ), majd a félidóben elvégzett értékelést (Kok Report, $2004)$ követően megújította a stratégiát $(E G, 2005)$. Az Unió stratégiájának hangsúlya 2006-ban a gazdasági növekedésen, a foglalkoztatottság emelésén és a tudásalapú (innovációkra alapozó) versenyképes gazdaság kiterjesztésén van. A stratégiának fontos része az egységes kutatási (és innovációs) térség, az ERA megteremtése, ${ }^{14}$ melyhez a kutatás-fejlesztési keretprogramok jelentik a fó pénzügyi forrást.

A visegrádi országok szereplése a keretprogramokban ugyan még alacsony szintú, ám a részvétel a csatlakozás óta dinamikusan bővül: a 4. keretprogram (1994-98) és az 5. keretprogram (1998-2002) adatait összevetve azt látjuk, hogy a cseh, lengyel, magyar vagy szlovák résztvevók közremúködésével futó projektek száma körülbelül megkétszereződött. A 6. keretprogram (2002-2006) adatai még nem ismertek, ám annyi tudható, hogy 2005 közepéig például 99 magyar koordinációjú pályázat volt sikeres, vagyis több, mint a teljes 5 . keretprogramban. ${ }^{15}$

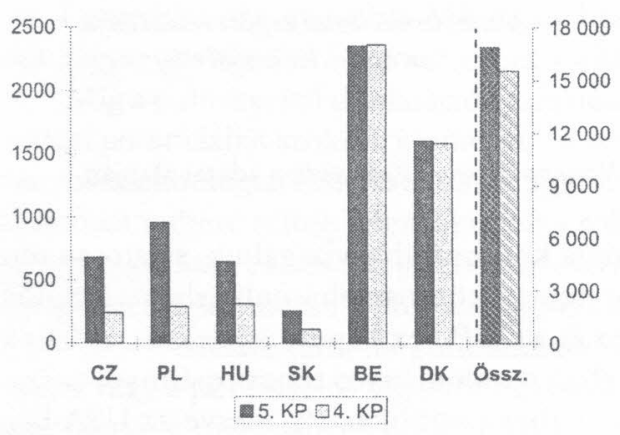

legalább egy szervezettel az adott országból

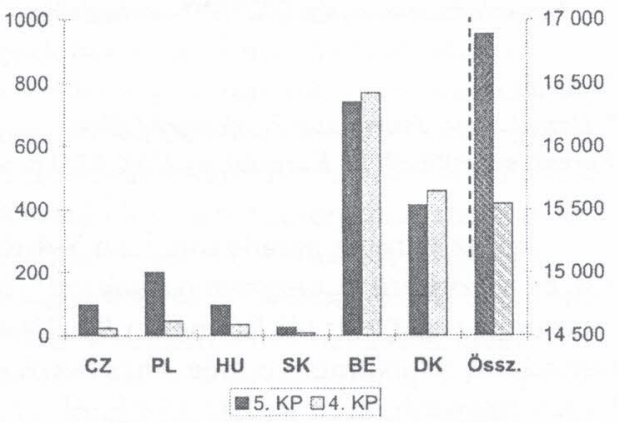

aะ adott országból koordináltan

8. ábra. A 4. és 5. Keretprogramban megvalósított projektek száma

Forrás: Community Research and Development Information Service (CORDIS)

\footnotetext{
${ }^{14}$ Az újragombolt lisszaboni stratégia az alábbi területeken irányoz eló gazdaságpolitikai beavatkozást: (i) hatékony belsố piac; (ii) szabad és tisztességes kereskedelem; (iii) jobb szabályozás; (iv) az európai infrastruktúra javítása; (v) befektetés a kutatás-fejlesztésbe; (vi) az innovációk felfuttatása; (vii) erôs ipari háttér megteremtése; (viii) több és jobb munkahely; (ix) rugalmas munkaerô; ( $x$ ) jobb oktatás, kiaknázható készségek. Lásd erról a lisszaboni stratégia honlapját: http://europa.eu.int/growthandjobs

${ }^{15}$ „Még több K + F siker várható.” Világgazdaság, 2005. augusztus 3.
} 
Az ERA-ban örvendetesen bôvülő részvételi lehetôségek mellett sem szabad megfeledkezni az arányokról: az 5. keretprogramban a Lengyelországhoz képest hetedakkora Dánia például több mint kétszer annyi projektet koordinált és másfélszer annyi kooperációban vett részt. Igaz, hogy ebben a periódusban Lengyelország még nem volt teljes jogú tag, ám a forrásokhoz - elvileg - ugyanolyan feltételek mellett fért hozzá, mint Dánia. A visegrádi országok összesen annyit szerepeltek a keretprogramokban, mint Belgium (és így még a minden bizonnyal jelentôs halmozódással ${ }^{16}$ sem számoltunk). Mindez azt is jelenti, hogy például a népességarányra vetített dán részvételi intenzitás eléréséhez a részvételi számoknak körülbelül meg kellene tizenötszöröződniük! Ha minden négy évben ${ }^{17}$ sikerülne a megkétszerezôdés, akkor is legalább 16 évnek kell eltelnie a jelenlegi dán szintre való felzárkózáshoz...

Az ERA megteremtését a keretprogramok technológiai jellegú prioritásain túlmenően - sokszor éppen a keretprogramokba beépítve - fontos európai szintú, azaz Brüsszelból koordinált gazdaságpolitikai akciók segítik, amelyek közül az alábbiakat az ERA kiépülését szolgáló mechanizmusok jobb megértéséhez idézem:

1. „Policy benchmarking”: A tagállami és az összeurópai innovációs teljesítmény stratégiai benchmarking elemzésének eredményeit évról évre részletes kiadvány mutatja be (lásd EC-Key Figures, Innovation Scoreboard). Az európai Trendchart (http://trendchart.cordis.lu) a tagállamok fố innováció-politikai lépéseit ismerteti. Mindennek az innovációpolitikát tudatosító és népszerúsítố hatása felbecsülhetetlen.

2. „Mapping of excellence”: A kiválóság feltérképezése 2001-tól kezdődóen vált divatossá. Ennek az a lényege, hogy egységes kritériumok segítségével próbálja meg jellemezni a $\mathrm{K}+\mathrm{F}$ legismertebb intézményeit egész Európában. A „mapping of excellence" három tudományos-technológiai területen valósult meg: az élettudományok, a nanotechnológia és a közgazdaságtan területén fóleg bibliometriai adatokkal (a publikációs adatok másodelemzésével, elsősorban ún. impakt faktorokkal) azonosították a kiváló intézményeket. A közgazdaságtani elemzésben nem szerepel V-4 ország, a nanotechnológiai területen minden V-4 országból egy-egy intézmény került a „Top 100” közé. Ennél is figyelemre méltóbb az élettudományi mapping: a „Top-100” között gyakorlatilag minden V-4 országban található egy-egy, ténylegesen a jobbak közé tartozó intézmény. A kiválóság feltérképezése nemcsak egyszerủen a tisztábban látást szolgálja, hanem versenyre is ösztönzi az európai kutatóhelyeket.

3. Regionális innovációs politikák összehangolása: Brüsszel külön akciókat indított, hogy a régiók innovációs politikái koherensebbé, a lisszaboni stratégiával jobban összehangolttá váljanak (Regions of Knowledge, Innovating Regions). Ezekben az akciókban egyre több V-4 régió vesz részt.

4. ERA-NET: a konkrét nemzeti $\mathrm{K}+\mathrm{F}$ programok összehangolását segítő program.

5. Elöretekintés (foresight): A technológiai előretekintést az EU elsôsorban azért ösztönzi, hogy az egyes országok innovációs és $\mathrm{K}+\mathrm{F}$ politikájával kapcsolatos (nö-

\footnotetext{
${ }^{16}$ Nyilván magas azoknak a projekteknek a száma, amelyekben több visegrádi ország is részt vesz. Ezeknek az elemzése nagyon fontos lehet annak megértéséhez, hogy milyen kutatási profilokban sikeresek a V-4-ek, erre az elemzésre azonban a jelen tanulmány keretei között nem vállalkozhattam.

${ }^{17}$ A 7. keretprogram már hét évig fog tartani (2007-2013).
} 
vekvô) kockázatokat idóben észleljék, és ha kell, európai választ tudjanak adni ezekre. Az elôretekintésnek is komoly integrációs hatása van.

6. CORDIS: Az Unió innovációs óriásportálja, amely a nagy európai nyelveken (angol, német, francia, olasz, spanyol) túl immár lengyelül is elérhetô. Ennek fontosságát jól érzékelteti, hogy a portál vezetô tisztségviselóje szerint amióta lengyelül is elérhető a portál, exponenciálisan nô a Lengyelországból odalátogatók száma...

A nyomásgyakorlás ${ }^{18}$ eszköztárába tartozó fenti gazdaságpolitikai akciók eredményeként kétségtelenül megfigyelhetô, hogy a tagországok (köztük a V-4-ek is) jóval elkötelezettebbé válnak a lisszaboni stratégia céljai iránt, mint egyébként lennének. Hozzá kell tenni azt is, hogy a felsorolt „policy” jellegú akciókban valamennyi visegrádi ország elfogadható intenzitással és objektivitással vesz részt.

A Budapesti Múszaki és Gazdaságtudományi Egyetem koordinálásával véghezvitt $R E C O R D$-projekt is az ERA kiépülését szorgalmazó, gazdaságpolitikai irányultságú program volt. Az EU által finanszírozott kiválóság kísérleti feltérképezése túllépett a hagyományos bibliometriai vizsgálatok keretein. ${ }^{19}$ A Benchmarking Kézikönyoben (2005) összefoglalt módszer alkalmazásával a V-4 országokban (továbbá Szlovéniában és Máltán) az ún. RECORD kiválósági központok három fajtáját különböztették meg, és törekedtek a kiváló vállalati $\mathrm{K}+\mathrm{F}$ feltérképezésére is:

1. A nemzetközi kiválósági központok kiemelkedő (nemzetközi szintü) kutatókat vonzanak; fontos kutatási eredményeket és innovációkat képesek felmutatni, melyeknek jelentős (európai, illetve nemzetközi) hatásuk van; hozzájárulnak a hazai (és így az európai) hozzáadott értékhez, jóléthez és életminőséghez; több tudományterület együttes alkalmazásával közel hozzák egymáshoz az alap- és alkalmazott kutatásokat; magas színvonalú, modern infrastruktúrával rendelkeznek; ipari célokra alkalmazható tudást állítanak elố; továbbá jellemzố rájuk a vállalkozásokkal kiépült többirányú és többszintú interakció, és olykor ágazati specializáltságuk is erôs.

2. A nemzeti kiválósági központok (az országhatárokon belül jelentős, ám csak csekély nemzetközi hatású $\mathrm{K}+\mathrm{F}$ egységek) szintén kiemelkedő kutatókat vonzanak (elsősorban a határokon belülról); fontos kutatási eredményeket és innovációkat képesek felmutatni, melyeknek jelentôs nemzeti hatásuk van, hozzájárulnak a hazai hozzáadott értékhez, jóléthez és életminôséghez; közel hozzák egymáshoz az alap- és alkalmazott kutatásokat; olyan kapacitásokkal rendelkeznek, amelyekkel ipari célokra alkalmazható tudás állítható elő; erôs ágazati elkötele-

${ }^{18} \mathrm{Az}$ Unió a lisszaboni csúcsot követốen vezette be, és azóta egyre szélesebb körben alkalmazza a nyílt módszerú koordináció (Open Method of Co-ordination, $O M C$ ) elnevezésű koordinációs mechanizmust. Ma már ez a legfóbb koordinációs elv. Ez rugalmas irányításon, önkéntes részvételen, közös és elérhetoó célokon, valamint szakértôi nyomásgyakorláson alapszik.

${ }^{19}$ A kiválóságot dinamikusan (azaz idôszakhoz kötôdôen) és az innovációkra koncentráltan értelmezô benchmarking kvantitatív és kvalitatív jellemzóket egyaránt alkalmazott. A francia Euroquality koordinálásában és a GKI Gazdaságkutató Rt. tudományos irányításával 2006-2007-ben az agrárgazdasági és élelmiszeripari K + F „kiválósági feltérképezésére” (mapping of excellence) kerül sor. Ez a vizsgálat is szakít a bibliometriai adatok kizárólagos használatával, és a publikációs adatok mellett online kérdôivet is használ. A kiválóság feltérképezéséhez innovációkra, szabadalmakra és vállalati kooperációban zajló kutatásokra vonatkozó adatokat használunk fel. 
zettséggel jellemezhetô kutatóintézmények; és a legkülönbözóbb szinteken lépnek kapcsolatba vállalatokkal.

3. A piaci résre specializálódott kiválósági központoknak helyi és regionális innovációs hatásuk van, vagy az innovatív tudás egy speciális réspiacán tevékenykednek: állami vagy magánkézben levó $\mathrm{K}+\mathrm{F}$ szervezetek, melyeket kiváló szakértelem jellemez; olyan kutatási eredményeket és innovációkat képesek felmutatni, melyek egy szúkebb körben hozzájárulnak a nemzeti - vagy világgazdasági - hozzáadott értékhez, jóléthez és életminőséghez; közel hozzák egymáshoz az alap- és alkalmazott kutatásokat; olyan kapacitásokkal rendelkeznek, melyekkel ipari célokra alkalmazható tudás állítható elő; és szoros kapcsolatban vannak vállalatokkal.

A RECORD-projektben részt vevô szakértói csapat hozzávetóleg meg tudta állapítani az első két csoportba tartozó kiválósági központok számát.

1. táblázat. RECORD nemzetközi és nemzeti kiválósági központok a V-4 országokban (2003)

\begin{tabular}{|l|c|c|c|}
\hline \multirow{2}{*}{} & \multicolumn{2}{|c|}{ RECORD } & \multirow{2}{*}{ Összesen } \\
\cline { 2 - 3 } & \multicolumn{2}{|c|}{ kiválósági központ } & \\
\cline { 2 - 3 } & 14 & 24 & 38 \\
\hline Csehország & 8 & 5 & 13 \\
\hline Lengyelország & 8 & 6 & 14 \\
\hline Magyarország & 3 & 5 & 8 \\
\hline Szlovákia & 33 & 40 & 73 \\
\hline Összesen & \multicolumn{2}{|c|}{} \\
\hline
\end{tabular}

Forrás: Kísérleti térkép (2005)

Az adatok szerint 2003-ban a visegrádi országokban nagyobb méretú, tudásukkal jelentôs innovációk megvalósításához érdemben hozzájáruló és az elért $\mathrm{K}+\mathrm{F}$ eredmények jelentôs hányadát a világpiacon értékesítő kutatóhelyek ${ }^{20}$ is találhatók, bár nem nagy számban, és jellemzóen a fốvárosok környékén. ${ }^{21}$ A V-4 régióban legfeljebb 40 -re becsülhetô azoknak a „nemzetközi kiválósági központnak” minősíthető KFI-intézményeknek a száma, amelyek a közeljövóben megállhatják helyüket a nemzetközi versenyben: ezek lehetnek az integrálódó ERA keleti zászlóshajói. Minden V-4 országban található továbbá figyelemre méltó „,ipari” hálózat tudás-központjává fejlő́dött nemzeti kiválósági központ intézmény. ${ }^{22}$ Végül néhány kisebb, szúk „,technológiai résre” specializálódott, és például jelentôs szellemi exportjának tanúsága szerint a világpiacon is vitathatatlanul versenyképes intézményt is érdemes megemlíteni. ${ }^{23}$

${ }^{20}$ A RECORD kiválósági központ fogalma nem egyezik meg az EU-keretprogramokban használtakkal. A problémát a Benchmarking Kézikönyv (2005) részletesebben is körbejárja.

${ }^{21}$ Közülük a Kísérleti térkép (2005) kötet a cseh Kibernetika Tanszék (Cseh Mû́szaki Egyetem), a lengyel Anyagtudományi és-Mérnöki Kar (Varsói Müszaki Egyetem), illetve a VIGO System Kft. és a magyar ComGenex Rt. benchmarkjait részletesen is ismerteti.

${ }^{22}$ Ebbe a csoportba tartozik a cseh Molekuláris és Gén-biotechnológiai Központ, valamint a magyar Gabonatermesztési Kutató Kht. (lásd Kísérleti térkép, 2005).

${ }^{23}$ A benchmarkok alapján a szlovák Nukleáris Kémia Tanszék (Comenius Egyetem) és a máltai Sejtfarmakológiai Intézet Kft. tartozik ide (lásd Kísérleti Térkép [2005]). 


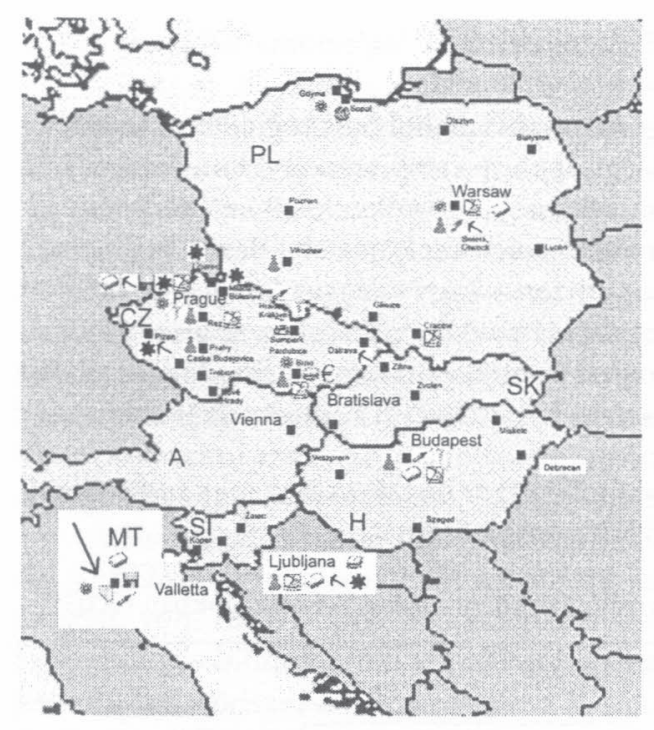

Potenciális nemzetközi kiválósági központok

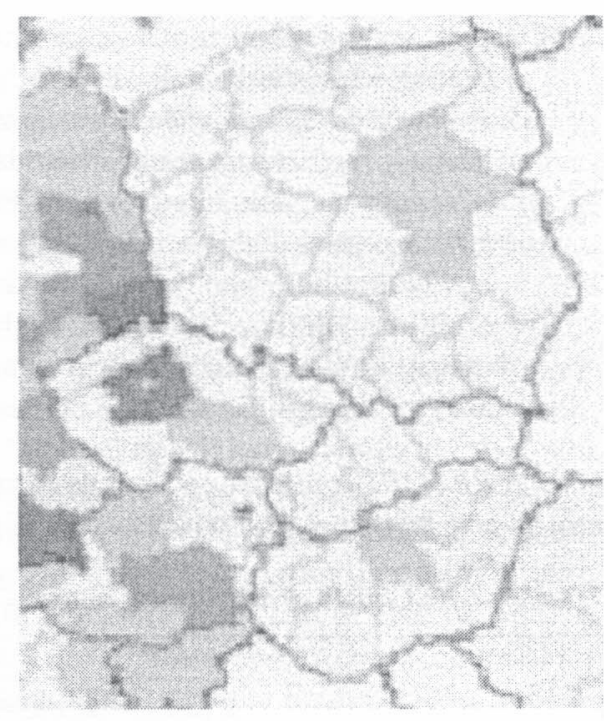

A $K+F$ ráfordítások regionális koncentrációja*

\section{9. ábra}

* Közép-Csehországban a GERD/GDP ráta 3\% feletti, Közép-Magyarországon, illetve a lengyel Mazowieckie régióban 1 és 1,9\% közötti értéket ér el.

Forrás: Kísérleti Térkép, (2005), illetve Eurostat: Regions: Statistical Yearbook 2005 (Panorama of the European Union)

Hangsúlyozni kell, hogy a visegrádi országok innovációs rendszereiben mindhárom típusú innovatív intézményre szükség van. ${ }^{24}$ Nagy probléma azonban, hogy sem nemzeti, sem nemzetközi kiválósági központok nincsenek meg a kritikus tömegben a V-4 országokban. Ahhoz ugyanis, hogy az ERA ezt a térséget is szervesen integrálni tudja, nagyrégiónként legalább 2-3 nemzetközi központ jelenléte volna kívánatos. Ezen túlmenốen sok nemzeti, illetve kisebb, piaci résre specializált központ meglétére is szükség van, hiszen az innovációkhoz szükséges kritikus tudásmennyiségnek az adott nemzetgazdaság egészében, hálózatokban „múködve” kellene megjelennie, fontos versenyképességi tényezóként. ${ }^{25}$

A regionálisan specializálódott kiválósági központok nem teremthetók meg mechanikusan, s ez indirekt módon a Lisszaboni Stratégiából is kikövetkeztethetố: nemcsak az innováció, hanem a növekedési (versenyképességi, termelékenységi) és a szabályozási (rugalmassági) tényezók is hangsúlyos elemei a programnak.

${ }^{24}$ A szakirodalom szerint a versenyképes regionális gazdaságok megteremtéséhez régiónként körülbelül 3 millió lakosra és a high-tech iparágakban 150 ezer fő foglalkoztatására van szükség (lásd Varga, 2004, 269), és ehhez okvetlenül szükségesek a $\mathrm{K}+\mathrm{F}$ intézmények is.

${ }^{25}$ Az evolucionista közgazdaságtan már régóta hangsúlyozza ugyanis, hogy a „tudás” hagyományos, kereslet- és kínálatorientált megközelítése nem ad teljes képet. A tudást hasznosító vállalatok maguk is új ismeretek létrehozói, a kutatóintézetek szintén hasznosítók stb. A lényeg a minél sokrétúbb interakció. 


\section{$A K+F$ és innovációs politika főbb irányai}

A fentiekból is látszik, hogy Brüsszel óriási eróket mozgósít az ERA megteremtésének érdekében. Nem véletlen tehát, hogy az Európai Unión belül a visegrádiak is nagyon igyekeznek, hogy megfeleljenek a lisszaboni stratégia célkitúzéseinek, ${ }^{26}$ hiszen a világ fejlettebb része az innovációkat és a kutatás-fejlesztést tekinti a „tisztességes” verseny elsődleges terepeinek: aki ezeken a területeken lemarad, jó eséllyel ki is marad a világ gazdasági javaiért folytatott sokszor egyenlốtlen küzdelemben.

A visegrádiak lázas törvénykezéssel is igyekeznek igazolni innovációs politikájukat az Unió felé: 2004-ben például cseh kormányrendelet született a K + F politikáról, 2005-ben pedig lengyel törvény lépett életbe a tudomány finanszírozásáról és az innovációs tevékenységek támogatásáról. A magyar innovációs törvény is 2005-ben lépett hatályba, csakúgy, mint Szlovákiában az új K + F finanszírozási törvény. Ugyanakkor nincs áttörés: az ERA egyik eszközeként szolgáló Trendchart „,szorgosnak, ám lassan formálódónak" minôsíti a V-4-ek nemzeti innovációs rendszereit, és rendszeresen bírálja az innovációért felelős kormányszervek közötti koordinálatlanságot, a regionális innovációs feladatok megvalósításának vontatottságát stb. (lásd Annual Innovation Policy Trends and Appraisal Report 2004-2005).

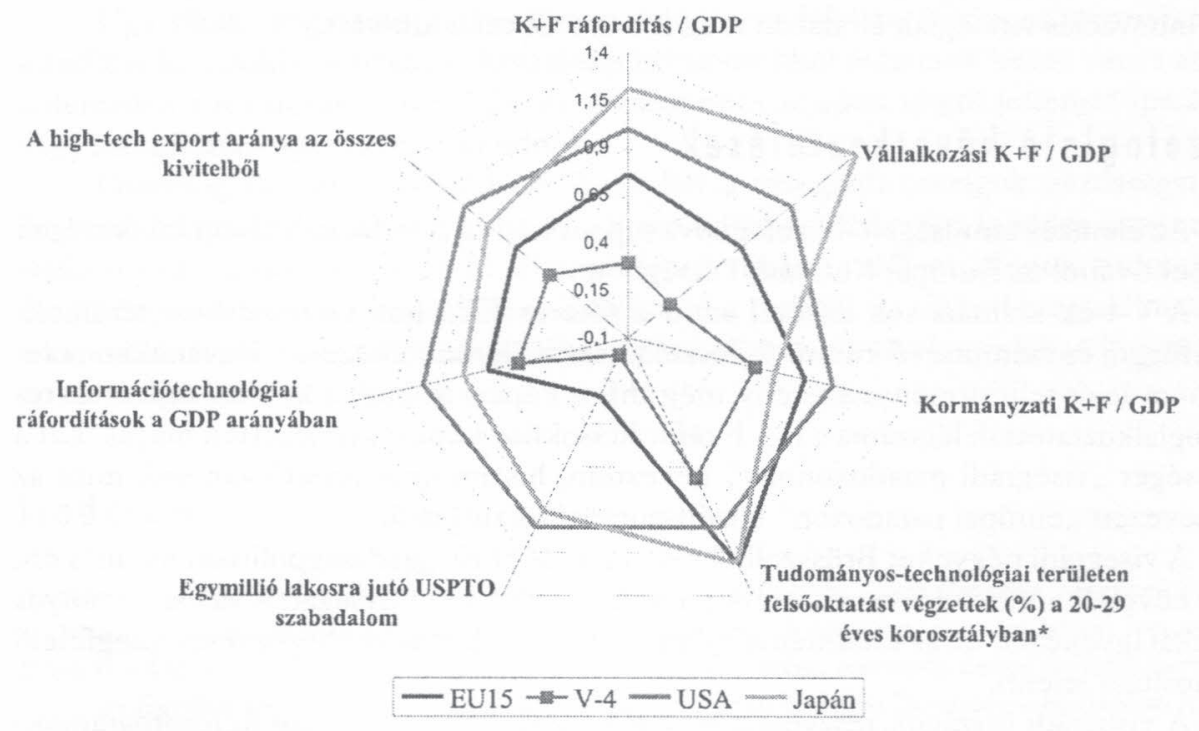

10. ábra. A visegrádi országok innovációs rendszerének néhány mutatója nemzetközi összevetésben: USA $=1(2002-2004)$

* A V-4 esetében súlyozatlan átlag.

Forrás: számítások az Eurostat adatai alapján.

${ }^{26}$ A lisszaboni stratégiáról késốbb még lesz szó. 
A visegrádiak igyekezete - dacára a kiindulópontokban említett V-4 deklarációnak - nem összehangolt, ${ }^{27}$ ebból a szempontból tehát volna mit tennie az éppen soros magyar elnökségnek. Az aktuális innovációpolitikai szándékok alapján a visegrádi országokban lassan terjed az a felismerés, hogy az innovációs rendszer múködése alapvető az országok jövôbeli versenyképességének alakulása, és így a felzárkózási ütem szempontjából. Az alacsony költségekre épülố versengést egyre szélesedő körben kellene felváltania a minôségre, az újdonságra és a hazai tudásra alapozott innovációkra épüló versengésnek, mivel az Európai Unión belül a bérek felzárkózásával, az árszínvonal és a termelékenységi szint kiegyenlítődésével folyamatos kihívás éri a hazai költség-versenyképességet. A globalizáció korában - amennyiben a termelési-szolgáltatási értékláncban nincs meg a megfelelố súlyú hazai tudás (hozzáadott érték) - a gazdaság sérülékennyé válhat, és a várt felzárkózás a bizonytalan jövóbe tolódhat el.

A V-4-ek innovációs rendszereit jellemzố alapmérôszámok közül pillanatnyilag sajnos egyik sem ígéri a gyors felzárkózás lehetőségét. Az adatok szerint a legsúlyosabb gondok a vállalati $\mathrm{K}+\mathrm{F}$ és innováció, illetve a múszaki-technológiai értelmiség utánpótlása terén vannak. A RECORD-projekt fontos tanulsága, hogy a visegrádi országokban csak nagyon kevés helyen és gyakran csak nagyon szük szektorokban vannak jelen kritikus tömegben olyan kutatócsapatok, amelyeket helyben nemzetközi szinvonalú ipari háttér is támogat. Az $E R A$-ba való sikeres integrálódás érdekében ezen biztosan változtatni kell, és a formálódó innovációs stratégiák általában meg is nevezik ezt a kihívást.

\section{Összefoglaló következtetések}

Az elemzés tanulságait összefoglalva sajátos kép rajzolódik ki a visegrádi országok perspektíváiról az Európai Kutatási Térségben.

A V-4-ek számára sok feltétel adott a sikeres ERA-beli szerepléshez: területük összefüggő, és számottevő kutató-fejlesztô létszám áll rendelkezésre. Ugyanakkor a régió innovációs teljesítménye szerény, még ahhoz képest is, hogy a kutatás-fejlesztés terén foglalkoztatottak létszáma a $\mathrm{K}+\mathrm{F}$ ráfordításokhoz képest kifejezetten magas. Ezt a jelenséget „visegrádi paradoxonnak” neveztem, hiszen nem másról van szó, mint az úgynevezett „,európai paradoxon” közép-európai torzulásáról.

A visegrádi négyeket Brüsszelból nagyon erốs külsô gazdaságpolitikai nyomás éri, hogy növeljék innovációs rendszereik múködésének hatékonyságát. A válasz látványos politikai igyekezet, de az eredményt eddig csak a problémák többé-kevésbé megfeleló tudatosítása jelenti.

A visegrádi országok részvétele az ERA-t leginkább jelképezó keretprogramokban örvendetes felfutást mutat, ám még mindig rendkívül alacsony szintú, ugyanakkor a gazdaságpolitikai akciók iránti elkötelezettségük töretlen. Jónak túnik tehát az a célkitúzés, hogy a V-4 országok hangolják össze innovációpolitikai programjaikat. Ugyanakkor ezen a területen nincs nagy külsố kényszer, s ezért nem is csodálkozhatunk azon, hogy a haladás lassú, holott a perspektíva adott.

${ }^{27}$ A V-4-ek elérhetô friss innovációpolitikai dokumentumai például nem is említik egymás országait. 
Az ERA-ba való integrálódás az innovációs folyamatok intenzívebbé válása nélkül nehezen valósítható meg, ám ezt jelentốs mértékben gátolja az intézmények rugalmatlan múködése. Ez a jelenség egyébként az átmeneti (transition) gazdaságok jellemzó vonása. Kimondhatónak túnik tehát az a sejtésünk, hogy a $\mathrm{K}+\mathrm{F}$ hatékonyságában és az intézmények múködésében észlelhetô elmaradások összefüggenek egymással. A témakör mindenesetre további vizsgálatokat igényel.

A fentiekból következốen a visegrádi országok $\mathrm{K}+\mathrm{F}$ és innovációs politikáját érdemes a teljes gazdaságpolitikai „mix” viszonylatában vizsgálni: meggyőzoódésem, hogy az ERA-ba való integrálódáshoz az innovatív (vállalkozási) magatartásformák bátorításának kell jelentenie a kiindulópontot.

Az integrált megközelítés az ERA kiépítését szolgáló lisszaboni stratégiának is jellemzố vonása: a megjelölt tíz beavatkozási terület közül három (az innováció, a $\mathrm{K}+\mathrm{F}$ és a humáneróforrások fejlesztése) közvetlenül köthető a tudásalapú gazdasághoz; s ezek mellett az Unió az egyes szabályozási területeken történó beavatkozásoktól, illetve az infrastruktúra javításától reméli a gazdasági növekedés kiteljesedését és a felzárkózást a versenyképesség terén. Nem hagyható szó nélkül azonban, hogy Japánban és az Egyesült Államokban a tudomány- és technológiapolitika a regionális folyamatokra, s ezek között is elsôsorban a klaszterépítésre és -fejlesztésre koncentrál, és ebben a tekintetben az európai stratégia még nem öltött annyira explicit formát.

Úgy tûnik, hogy a regionális bekapcsolódás az ERA-ba bizonyos mennyiségi és minôségi korlátokba is ütközik: kiválósági központokból még csak kevés van, s azok is jellemzóen a fốvárosok környékén, és sokszor nem az adott régiót jellemzó iparágban vagy szolgáltatási ágazatban múködnek.

Összefoglalásként elmondható, hogy bár a visegrádi országok gazdaságai többé-kevésbé integrálódtak az EU-ba, $\mathrm{K}+\mathrm{F}$ szektoruk továbbra is a fejlődés átmeneti fázisában van. Sajnos nem elég büszkének lenni néhány valóban jelentôs tudományos eredményre, a szektor integrációja csak akkor lesz realitás, ha sikerül megtalálni azokat a kapcsolódási pontokat és interakciókat a gazdasággal, amelyek a valóban korszerú innovációs rendszerek jellemzói.

\section{Irodalom}

Annual Innovation Policy Trends and Appraisal Report 2004-2005. Czech Republic, Hungary, Poland, Slovakia. European Commission, DG Enterprise - European Trendchart on Innovation.

Borsi B. - Dévai K. -Papanek G. (szerk.) (2005): Kísérleti térkép: innovatív kutató-fejlesztốszervezetek az Európai Unióhoz csatlakozó országokban. Budapest: Európai Bizottság - Budapesti Múszaki és Gazdaságtudományi Egyetem - GKI Gazdaságkutató Rt.

Borsi B. - Dévai K. - Papanek G. - Rush, H. (szerk.) (2005): Benchmarking Kézikönyv az Európai Unióhoz csatlakozó országok innovatí kutató-fejlesztố szervezetei számára. Budapest: Európai Bizottság - Budapesti Múszaki és Gazdaságtudományi Egyetem.

Borsi, B. - Papanek, G. (szerk.) (2002): Az Európai Unió 6. Keretprogramjában való magyar részvétel lehetóségei. Kutatási zárójelentés az Oktatási Minisztérium részére. Budapest: BME Heller Farkas Innovációs Kutatócsoport - GKI Rt., 100.

Borsi, B. (2005): A vállalkozási környezet és a hazai versenyképesség. Európai Tükör, 2005. november. 
Coase, R. H. (1937): The Nature of the Firm. Economica, 4. 386-405.

EC (2000a): Presidency conclusions. Lisbon: European Council, 23-24 March 2000.

EC (2000b): Towards a European Research Area. Communication from the Commission to the Council, the European Parliament, the Economic and Social Committee and the Committee of the Regions, Brussels.

EC (2002a): Towards a European Research Area. Science, technology and innovation. Key Figures 2002. European Commission - DG Research.

EC (2002b): Presidency conclusions. Barcelona: European Council, 15-16 March 2002.

EC (2004): Innovation in Europe - Results for the EU, Iceland and Norway. Luxemburg: ECEurostat.

EC (2005): Presidency conclusions. Brussels: European Council, 22-23 March 2005.

Kok Report (2004): Facing the challenge. The Lisbon Strategy for growth and employment. Report from the High Level Group chaired by Wim Kok. Luxembourg: November 2004.

OECD (1997): National Innovation Systems. Paris: OECD.

OECD (1998): Technology, productivity and job creation. Best policy practices. Paris: OECD.

OECD (2002): Frascati Manual 2002: Proposed Standard Practice for Surveys on Research and Experimental Development. OECD, Paris.

OECD (2005): Oslo Manual: Guidelines for Collecting and Interpreting Innovation Data. $3^{\text {rd }}$ Edition. Paris: OECD.

Papanek G. (2003): Az európai paradoxon a magyar K + F szférában. Fejlesztés és Finanszírozás, 2003, 4. sz. 40-47.

Török, Á. (with Borsi, B. - Telcs, A.) (2005): Competitiveness in Research and Development. Comparisons and Performance. Cheltenham UK: Edward Elgar, 251.

Varga A. (2004): Az egyetemi kutatások regionális gazdasági hatásai a nemzetközi szakirodalom tükrében. Közgazdasági Szemle, 2004, 3. sz. 